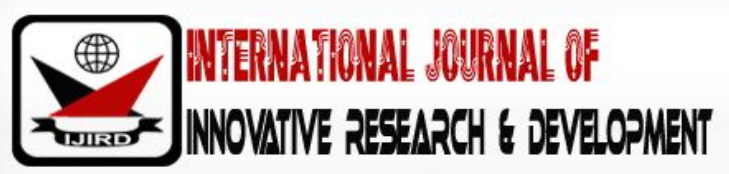

ISSN 2278 - 0211 (Online)

\section{Factors of Production and Their Effects on the Contributions of Sole Proprietorship Businesses to the Economic Development of Developing Countries: The Case of Ghana}

\author{
Nelson Kofi Adarkwah \\ Lecturer, Department of Secretary ship and Management Studies, Sunyani Technical University Ghana \\ Dauda Abdulai \\ Lecturer, Department of Liberal and Languages Studies, Tamale Technical University, Ghana \\ Bempong Emmanuel Kofi \\ Senior Lecturer, Department of Communication Studies, Sunyani Technical University, Ghana \\ Dr John Poku \\ Director, International Affairs, Kumasi Technical University, Ghana
}

\begin{abstract}
Unemployment is seen as a big problem for both developed and developing countries Simmons, (2016). It (unemployment) is typically understood as the condition of not having a paying job even though the person is willing to work. For Romero, (2014) governments alone cannot solve unemployment problem in a given country so individuals, groups or families should set up businesses to complement governments' efforts. The study investigated the factors that influence sole proprietorship business in Ghana and how those factors affect their contributions to the economy. To carry out the study the researchers relied on three research questions which included factors that influence sole proprietorship businesses in Ghana, how the activities of sole proprietors are monitored in Ghana among others. A descriptive survey design which aims at obtaining information concerning the current status of a phenomena to describe 'what exists' with respect to variables or conditions in a situation was used. Questionnaires, interviews and observation guides were the instruments used for the study. Both Nwana (2005) and Fisher et al (2008) methods of sample size determination were used for the study. One thousand eight hundred and fifty-four respondents constituted the sample size for the study. The study disclosed that inadequacies in factors of production negatively affected the contributions of sole proprietors to the Ghanaian economy.
\end{abstract}

Keywords: Sole proprietors, inadequacies, raw materials, government policies, contract, inflation

\section{Introduction}

Every business organization needs factors of production to be able to survive and make meaningful impact in its area of operation. Factors such as land, labour, capital and entrepreneurship are factors known to influence production so far as businesses are concerned. Notwithstanding the above traditional factors of production, there are equally some factors like time, government policies, technical know-how, inflationary periods and exchange rates that can positively or negative affect the production levels of a business organisation.

\subsection{Literature Review}

Unemployment (or Joblessness) occurs when people are without work and are seeking for work (Romer 2011). For Keynes (2016) a person is unemployed if the person is (a) not working (b) currently not having available work and (c) seeking work. According to ILO report. (2010) over 197 million people globally or $6 \%$ of the world's workforce were without jobs in 2012. Essia et al (2012) said that over 74.2 million youth were unemployed in 2012.

Unemployment may have expression in the following ways namely functional unemployment, which occurs as a result of the time people take to move between jobs, structured unemployment which occurs due to mismatch of skills in labour market and classical or real major unemployment; which is prevalent in a competitive labour market when labour is pushed above the equilibrium. There is also voluntary unemployment where people choose to remain unemployed and finally demand deficiency or cyclical unemployment which occurs when the economy is below full capacity For example in recession 
unemployment tends to rise rapidly and firms lay off workers (Katz, (2010). For Karmer et al (2011) unemployment in developing countries is caused by; no employment opportunities created, difficulty in self- employment, poor health conditions, government or groups stopping others and lack of training opportunities.

The Ministry of Youth Employment in Ghana (2006) named the following among others as causes of unemployment in Ghana; introduction of the J S and Senior High School system of education without adequate planning for integration into trade/ vocations and job placements, shrinking public sector employment opportunities coupled with relatively slow growth of the private sector and lack of coherent national employment policy and comprehensive strategy to deal with unemployment problem. For Morris et al (2006) starting a new business can be both exciting and frightening because there are many practical things for a prospective businessman/ woman to consider; location, size, employees' quality and others. In this study factors such as credit facilities, labour, raw materials, knowledge capacity, government policies and inflationary periods (exchange rates) are held constant so a close examination would be placed on them to determine whether or not inadequacies in them could have negatively or positively results on the performance of sole proprietors to the Ghanaian economy.

\subsection{Statement of the Problem}

The issue of unemployment is a challenge to governments in both developing and developed countries (Romer 2011) as already mentioned. In Ghana for example since independence successive governments have tried to contain the problem by adopting different strategies. Dr. Kwame Nkrumah instituted the Workers' Brigade in the 1960s to contain the problem. The J.A. Kuffour's administration (2008) brought into the lime light the National Youth Employment Programme which was continued by the J E A Mills administration and the Mahama administration. Despite these efforts by the various governments, they all came to realise that the private sector was needed to complement the efforts of the government. Interestingly, many Ghanaian set up their own businesses to complement government's efforts but unfortunately many of them face problems with government bodies and other factors within the economy that mitigate against the smooth running of the business set up.

When one considers the numerical strength of sole proprietors in Ghana and all other factors that influence business in the country, would sole proprietors have performed better if factors affecting them are held constant or controlled well? In this light the study therefore sought to find out the extent to which sole proprietors react to inadequacies in factors of production that affect their businesses so that appropriate measures could be put in place to enable them to perform creditably for the proper development of the country. This is so because it is imperative for a researcher to explore why there are relatively a greater numbers of sole proprietors in Ghana but their contributions to national development is minimal?

\subsection{Objectives of the Study}

The study was geared towards two main objectives which were general and specific. Generally the study aimed at adding to the body of knowledge in the area of factors affecting sole proprietors in their production processes and the specific objectives among others included first, to inquire into factors that affect the operations of sole proprietors in Ghana. Second to obtain insight into the dynamics of sole proprietorship businesses for the economic development of the Ghana an economy and lastly to find out some of the regulatory/ monitoring agencies of sole proprietors in Ghana.

\begin{tabular}{|c|c|c|c|c|}
\hline $\mathbf{S} / \mathbf{N}$ & Research Objectives & Research Questions & Research Finding & Relevance of the Study \\
\hline 1. & $\begin{array}{l}\text { Enquire into factors } \\
\text { that affect the } \\
\text { operations of sole } \\
\text { proprietors in Ghana }\end{array}$ & $\begin{array}{l}\text { What factors affect } \\
\text { the sole } \\
\text { proprietorship } \\
\text { business in Ghana? }\end{array}$ & $\begin{array}{l}\text { Factors like government regulations, } \\
\text { inadequacies in factors of production } \\
\text { and competition affect among others } \\
\text { affect sole proprietors in Ghana }\end{array}$ & $\begin{array}{l}\text { Policy makers/ stakeholders } \\
\text { owners of Sole } \\
\text { Proprietorship businesses } \\
\text { and other researchers }\end{array}$ \\
\hline 2. & $\begin{array}{l}\text { Find out some of the } \\
\text { regulatory bodies of } \\
\text { sole proprietors in } \\
\text { Ghana }\end{array}$ & $\begin{array}{l}\text { How are the } \\
\text { activities of sole } \\
\text { proprietors } \\
\text { monitored or } \\
\text { regulated in Ghana? }\end{array}$ & $\begin{array}{l}\text { The Ghana Tourist Board, The Ghana } \\
\text { Revenue Authority, The National Board } \\
\text { for Small Scale Businesses among } \\
\text { others regulates sole proprietors in } \\
\text { Ghana }\end{array}$ & $\begin{array}{c}\text { Policy makers, owners of } \\
\text { sole proprietorship } \\
\text { businesses and other } \\
\text { researchers }\end{array}$ \\
\hline 3. & $\begin{array}{l}\text { Obtain insight into } \\
\text { the dynamics of the } \\
\text { sole proprietorship } \\
\text { business in Ghana }\end{array}$ & $\begin{array}{l}\text { What are the effects } \\
\text { of factors of } \\
\text { production on } \\
\text { production levels of } \\
\text { sole proprietors in } \\
\text { Ghana? }\end{array}$ & $\begin{array}{c}\text { Low production levels, inability to fulfil } \\
\text { obligation to the government and the } \\
\text { society and collapse of some } \\
\text { businesses }\end{array}$ & $\begin{array}{l}\text { Policy makers, stakeholders } \\
\text { in business administration, } \\
\text { and other researchers }\end{array}$ \\
\hline
\end{tabular}

Table 1: Main Research Findings of the Study Source; Field Study 2016 


\subsection{Research Questions}

The following research questions guided the study.

- What factors affect sole proprietorship businesses in Ghana?

- How are the activities of sole proprietors monitored in Ghana?

- What are the effects of inadequacies in factors of production on the production levels of sole proprietors in Ghana?

\subsection{Significance of the Study}

Findings from the study would expose some of the inadequacies in factors affecting sole proprietors' production levels in Ghana. Such revelations could provide authorities or stakeholders in business administration some information upon which they could make decision regarding factors affecting sole proprietorship businesses in Ghana. Other government agencies like the Ghana Revenue Authority (GRA) and National Bureau for Small Scale Businesses (NBSSI) could adopt recommendations from the study to develop strategies that can enhance their performance.

Results from the study could be a stepping stone for future researchers who would be interested to have further studies in this area of study. Lastly results of the study could be applied to other business set ups that have similar characteristics like the sole proprietorship business.

\subsection{Limitations of the Study}

The researchers could not conduct the study to cover the whole country because sole proprietorship businesses in Ghana are numerous and varied and they are scattered throughout the length and breadth of the country. Such a research could be tedious and surmounting so the researchers used the Nwana (2005), Filer et al (2008) and convenient sampling methods to select the sample size for the study. Some respondents gave selective answers to some questions on the questionnaire may be because they felt that the research was aimed at exposing them to government agencies to be identified and taxed. A few of them even failed to answer questions asked on the questionnaire and some did not submit the questionnaire to the researchers for the reason that questionnaire given to them have been misplaced. It is however stated that despite the identified limitations among others efforts were made to ensure that the needed sample size was attained for the study.

\subsection{Delimitation}

The study was delimited to sole proprietors in developing countries with Ghana as a case point.

Findings from the study are therefore limited to only sole proprietors in Ghana. The study concentrated on sole proprietors who transacted business on table tops to those who owned kiosks or those who had warehouses. This means that sole proprietors who carry their wares on top of their heads and had no permanent places to transact business were not included in the study but the 'Waakye' seller for example who sells her rice on top of a table at a permanent place was included. This was so because the 'Waakye' sellers could be contacted easily at her place of work, (observed and interviewed) than the one who has no permanent place to transact business. This can lead to double counting of business owners if care is not taken.

\section{Methodology}

The research design for the study was descriptive because the study was aimed at obtaining information on what existed on factor that served as impediments on the performance of sole proprietors so far as shake-ups in factors of productions are concerned. The total sample size for the study was 2207 respondents but because $5 \%$ of sole proprietors who were given questionnaires either failed to return the questionnaire to the researchers or failed to give selective answers to some questions on the questionnaire, 2142 respondents were used for the study. The Z score for the study was $95 \%$ with a margin of error of 5\%. The 2142 respondents consisted of 1300 sole proprietors who were given questionnaire to fill but because there were some inappropriateness on some of the questionnaire, an average of 1285 respondents were taken as sole proprietors who were given questionnaire to fill, Three regions in Ghana namely, Upper West Region, Ashanti Region, and Western Region were conveniently selected for the study. The idea was that the Upper west region will provide information on sole proprietors from the northern part of the country, the Ashanti region will give information about sole proprietors in the middle belt of the country and the Western region would provide information on sole proprietors who reside in the southern sector of the country.

\subsection{Instruments}

A combination of questionnaire, observation guides and interview guides was used for the study. A thirty item questionnaire was designed for the study, the questionnaire was in three sections, thus A B and C. Section A dealt with personal data of respondents, B dwelt on issues that affect the level, nature and scope of production of sole proprietors for the development of their countries. Section C dealt with monitoring/ regularity sole proprietors in Ghana and how inadequacies in factors of production affected their production. Two hundred sole proprietors and other stakeholders in business administration were interviewed and fifty observations on activities of sole proprietors were undertaken. 


\section{Data Analysis}

Data from the completed questionnaire were analysed using STATA II

\subsection{Presentation of Data}

\begin{tabular}{|c|c|}
\hline Number of Obs Ervations & $\mathbf{1 3 0 0}$ \\
\hline $\mathrm{F}(23,1005)$ & 10.71 \\
\hline Prob>F & 0.00 \\
\hline R-square & 0.239 \\
\hline Adjusted R-square & 0.219 \\
\hline STD error of estimate & 0.3504 \\
\hline Durbin Waston & 1.98 \\
\hline Hetroskedasticity & 1.34 \\
\hline Chi2 & 0.248 \\
\hline Prob>Chi2 & 6.24 \\
\hline Mean VIF & \\
\hline
\end{tabular}

Table 2: Diagnostic Test Model

Source: Field Study 2016

Many researchers including Hunjira et al (2014) Ibrahim (2015) and Padachi (2017) have noticed that inadequacies in dependent variables are mostly attributable to the performance of the independent variables. From the diagnostic model it is evident that the model has a good fit. The adjusted R-squared value of 0.239 indicates that about $24 \%$ of changes in the dependent variable (production of sole proprietors) are attributable to the independent variables (factors of production). This is further supported by the significance of the F-statistics that indicates that the explanatory variables together well explain the dependent variable. The Dubbin Watson value approximately two (2) indicates the absence of autocorrelation. According to the rule of thumb as suggested by Field (2009), values less than 1 or greater than 3 are definitely causes of concern. However, values closer to 2 are less problematic depending on the sample and model. Furthermore the insignificance of the heteroscedasticity is also an indication of homoscedasticity. The mean variable inflation factor (VIF) of 6.34 indicates low co linearity between the independent variables considered the model. Literature has it that small intercorrelations among the independent variables are stable at the VIF +1 but when the VIF $>10$ then co linearity is a problem and the model needs to be checked.

\begin{tabular}{|c|c|c|c|c|}
\hline Factor of Production & Coefficients & Std Err & T & P>Iti \\
\hline Constant & -0.2990 & 0.1655 & -1.81 & 0.71 \\
Credit inadequacy & -0.4175 & 0.0982 & -4.25 & 0.000 \\
Labour inadequacy & -0.1536 & 0.0518 & -2.97 & 0.003 \\
Raw materials inadequacy & -0.0052 & 0.0015 & -3.49 & 0.001 \\
Knowledge capacity & -0.1409 & 0.0388 & -3.63 & 0.000 \\
Government policies & -0.1089 & 0.0295 & -3.70 & 0.000 \\
Higher inflation/ exchange rate & -0.1694 & 0.0470 & -3.60 & 0.000 \\
& & & & \\
\hline
\end{tabular}

Table 3: Factors of Production and Their Effects on the Production of the Sole Proprietor in Ghana Source: Field Study, 2016

From table 2 the following are seen. Credit in adequacies of sole proprietors negatively influences production at a statistical significance level of $10 \%$. This implies that sole proprietors who are troubled by capital or credit inadequacies are highly challenged in their production levels. Also labour inadequacies negatively influence the production levels at a statistical level of $1 \%$. This means that sole proprietors who are stiffened by labour availability find it difficult producing the required 
level of goods and services. It can then be said that as many sole proprietorship businesses can employ a maximum of five workers as indicated by Dzidonu (2003) and Abor (2010) then sole proprietors in Ghana at the time of the study were incapable at producing at higher levels so they could not contribute meaningfully to the development of the country.

Table 2 further shows negative relationship between government policies and the production of sole proprietors in Ghana at a statistical significant level of $1 \%$. This implies that government policies like taxes, regulatory laws, inflation and exchange rates negatively influence the production levels of sole proprietors.

The following monitoring bodies monitor the activities of some sole proprietors in Ghana. According to the respondents, The Ghana Tourist Board and the Association of Hotels in Ghana monitor/ regulate the activities of hotels in the country. The Ghana Revenue Authority, Ghana Food and Drugs Board, Ghana Standard Board and the Environmental Protection Agency are some other regulatory bodies for sole proprietors in Ghana. There are other union agencies like the Garages Association officers, Officers from the Regional Poultry Farmers Association and the police, monitor the activities of sole proprietors in Ghana.

\section{Conclusion}

Findings from the study indicated that inadequacies in the factors of production for sole proprietors negatively affected their production levels. The implication is that in as much as sole proprietors' production levels have been impeded by factors beyond their control their incomes could be affected. Their low incomes could mean that they are handicapped in their investment levels; thereby perpetuating the vicious cycle of poverty thus: low income $\Rightarrow$ low production $\Rightarrow$ low investment. When this cycle continues for long and stringent government policies are added to the woes of such business owners, they become paralysed and even fold up. The result is that their impact to the economic development of the country would be minimal if not negligible.

\section{Recommendations}

The following recommendations are provided in terms of contributions of sole proprietors to the economic development of Ghana with regard to their factors of production.

To begin with, as it is seen that inadequacies in all the factors of production negatively affect the performance of sole proprietors, stakeholders should ensure that all those factors that have negative impact on the activities of sole proprietors be dealt with tactfully. For example the NBSSI should be up and doing by opening its doors to as many sole proprietors as possible. This is so because the researchers came to realise that many sole proprietors were not aware of the existence of the institution. Again corrupt government officials who monitor the activities of sole proprietors should be fired to serve as deterrent to others because some sole proprietors whispered to the researchers' instances where some officers duped them. Banks and other financial institutions should try to reduce their credit rates and have moderate terms for their clients.

Again sole proprietors should be prepared to motivate the few workers they have employed and have trust in them. This could be made possible if measures are put in place so that owner/ managers would be able to employ the right calibre of workers motivate them so that they could put in their best for the growth and survival of the business set up. This will create the sense of belongingness in workers so that some seemingly negative habits in them (employees) that could bring mishap to the owner/ manager and affect the business may be stopped if not totally eliminated.

Lastly, the government should be able to handle inflationary periods and high exchange rates tactfully so that these do not affect the performance of the sole proprietors and their contribution to economic development of the country on one hand and be a headache to the government in income generation on the other.

\subsection{Further Research}

This research focused on the factors of production and how their inadequacies affect the production levels of sole proprietors. It will be appreciated if another research could be done to find out whether or not such inadequacies in factors of production at the statistical levels identified have the same impact on other businesses which are not sole proprietorships.

\section{References}

i. Abor, J. \& Quartey, D. (2010). Issues in SME development in Ghana and South Africa. Investment Research Journal of Finance and Economics. Euro Journal Publishing Inc

ii. Agovino, M. \& Rapposelli D. (2014). Employment of disabled people in the private sector. An analysis at the level of Italian Provinces according to article 13 of law 68/ 1999.Quality and Quantity. 48(1) 113-123.

iii. Aryon, J. (2014). Radical possibilities: Public policy urban education and a new social movement. Rutledge

iv. Berry, A. (2009). the economies of SMEs in South African Trade Industry Policy Strategies Report. Johannesburg.

v. Castles, S., De Haas, H., \& Miller, M. T. (2013). The age of migration: International population movements in the modern world. Palgrave. Mcmillan.

vi. Cull, R., Ku, L. C., Yang, X., Zhou, L. A., \& Zhu, T. (2017). Market facilitation by local Government and firm efficiency. Evidence from China. Journal of corporate Finance, 42 460-480.

vii. Dabo, D. A. (2006). Financing of small and medium sized enterprises in Nigeria. Ibadan 
viii. Edmisson, K. D. (2007). Role of small and large businesses in economic development. Community Affairs Department. Federal Reserve Bank. Kansas, USA.

ix. Essia, U. \& Ayara, N. (2012). Jobless Growth. The active poor phenomenon and growth, employment in Cross River State, Nigeria. Learning policies from Europe 2020Flagship Initiative Agenda for new skills and jobs. Science Journal of Economics 2012.

x. Fisher, A. A., Laind, E. T., Stoeckel, E. J. \& Townsand, W. J. (2008). Handbook for Family planning operations research design. (2nd ed). New York: Population Council.

xi. Hisrich, R. D., \& Ramadani, V. (2007). Organizing an Entrepreneurial venture in Effective entrepreneurial management. 101-114. Springer International Publishing.2017.

xii. International Labour Organization. Bureau of Statistics (2014). Measurement of employ-ment; unemployment and underemployment. Current International Standard and issues in their application.

xiii. Katz, L. (2010). Long-term unemployment in the Great Recession. In Testimony for the Joint Economic Committee. US Congress.

xiv. Keynes, J. M. (2016). General theory of employment, interest and money. Atlantic Publishers and Distributors.

xv. Kongolo, M. (2010). Job creation yrs. job shedding and the role of SMEs in Economic Development. African Journal of Business Management. Vol 4 (11) 2255-2285.

xvi. Kramer,M. R. \& Porter, M. (2011). Creating shared value. Harvard business review.89 (12) 62-77

xvii. Lofstrom, M. (2004). Labour market assimilation and the self-employment decision of Immigrant entrepreneurs. In how labour migrants fare. 191-222

xviii. Marlow, S., \& McAdam, M. (2013) Gender and entrepreneurship: Advancing debate and Challenging myths: explaining the mystery of the under-performing female Entrepreneur. International Journal of entrepreneurial behaviour and research.19 (1). 114-124

xix. Martinex, - Fernandex, C., Andirac, I., Fol, S., \& Cunning-Sabot (2012). Shrinking cities: Urban challenges of globalization. International Journal of Urban and Regional Research. 36 (2) 213-225.

xx. Morris, M. H., Miyasaki, N. N., Watters, C. E. \& Coombes, S. M. (2006). the dilemma of growth. Understanding venture size choices of women entrepreneurs. Journal of Small Business Management. 44 (2) 221-244.

xxi. Nwana, O., C. (2005). Introduction to educational research. Ibadan: Heinemann Educational Press.

xxii. Pitcher, J. (2013). Sex work and modes of self-employment in the informal economy. Diverse business practices and constraints to effective working. Social policy and society. 14 (1) 113-123

xxiii. Romer, D. (2011). Unemployment. Advance Microeconomics: (4th ed). New York: McGraw-Hill. 456-512.

xxiv. Simmons, J. (Ed). (2015). the education dilemma: Policy issues for developing countries in the 1980s. Elsevier.

xxv. Skokic, V., Lynch, P., \& Morrison, A. (2016). Hotel entrepreneurship in a turbulent Environment. International Journal of Hospitality management. 53 (2016) 1-11.

xxvi. Storey, D., J. (2016). Understanding the small business sector. Rout ledge.

xxvii. West head, P., \& Solesbik, M. Z. (2016). Entrepreneurship education and entrepreneurship Intention: Do female students benefit? International Small Business Journal 34 (8) 979-1003.

xxviii. White, A. (2017). Polish families and migration since E. U. accession. Policy Press

xxix. Zoltan, J. Acs (2007). How is entrepreneurship good for economic growth? Economic Conference of progress foundation. American Institute for Economic Research. Great Barrington. Massachusetts. 